\title{
DISSONÂNCIAS À ESQUERDA: A POLOP, O GOLPE E A DITADURA MILITAR
}

\section{EURELINO COELHO (UEFS/LABELU)}

Universidade Estadual de Feira de Santana

Laboratório de História e Memória da Esquerda e das Lutas Sociais

eurecoelho@uefs.br

\section{RESUMO}

$\mathrm{O}$ artigo analisa documentos que registram o modo como a POLOP caracterizou e interpretou o golpe de 1964 e a ditadura iniciada então no Brasil. É possível situar a POLOP numa posição singular entre as organizações marxistas brasileiras não apenas como formuladora de uma estratégia socialista alternativa à do PCB, mas também de opções táticas elaboradas para as diferentes conjunturas.

\section{Palavras Chave}

POLOP; organizações marxistas brasileiras; partidos e organizações de esquerda; ditadura civil-militar (1964-1985).

\section{ABSTRACT}

This article analyses documents that reveals how did POLOP recognize and interpret 1964 state coup and the dictatorship that took place then in Brazil. It is possible to see POLOP occupying a singular position between Brazilian Marxist organizations not just as developer of a socialist strategic other than that formulated by $\mathrm{PCB}$, but as proponent of tactical options elaborated for distinct conjunctures.

\section{Key Words}

POLOP; Brazilian marxist organizations; leftist parties and organizations; civil-military dictatorship (1964-1985). 


\title{
DISSONÂNCIAS À ESQUERDA: A POLOP, O GOLPE E A DITADURA MILITAR $^{2}$
}

\section{EURELINO COELHO (UEFS/LABELU)}

Universidade Estadual de Feira de Santana

Laboratório de História e Memória da Esquerda e das Lutas Sociais

eurecoelho@uefs.br

\begin{abstract}
A História das esquerdas durante a ditadura militar é um campo de batalhas. Nossa contribuição nesse combate é uma reflexão, ainda preliminar, sobre a trajetória da Política Operária, ou POLOP, como ficou conhecida uma dessas organizações de esquerda que lutou contra a ditadura e que editava um periódico com o mesmo nome. Fundada três anos antes do golpe e desaparecida nos primeiros anos 80, a POLOP ocupou uma posição especial na esquerda marxista brasileira, campo em que o peso do PCB foi sempre muito grande. Os marxistas de cuja articulação originou-se a POLOP haviam percorrido trajetórias distintas, mas tinham em comum a aversão às teses do PCB sobre a estagnação do desenvolvimento do capitalismo no Brasil devido à sobrevivência de "restos feudais" e pela dominação imperialista. Recusavam, ainda mais enfaticamente, o corolário dessas teses: a teoria da revolução nacional democrática que implicava, ao menos após a Declaração de Março de 1958, em aliança estratégica com a burguesia nacional.
\end{abstract}

A POLOP se caracterizou, desde o início, pela originalidade das formulações teóricas e programáticas que, nos anos seguintes, alcançariam repercussão significativa, ainda que minoritária, nos meios políticos e intelectuais de esquerda. Em síntese: o Brasil é uma sociedade capitalista, portanto, o conflito principal se dá entre a burguesia e o proletariado, sendo um erro muito grave acreditar, como o PCB, no caráter revolucionário da burguesia nacional. Além disso, o capitalismo se desenvolve no Brasil justamente a partir da reprodução de laços de dependência com o imperialismo, de tal modo que a luta contra o imperialismo adquire, imediatamente, caráter de luta anticapitalista. Por isso a tarefa principal dos marxistas no Brasil deveria ser a construção dos instrumentos de organização e conscientização independente da classe operária, libertando-a tanto da tutela burguesa exercida pelo Estado (através, sobretudo, da estrutura sindical corporativa e do PTB) quanto da direção reformista empreendida pelo PCB. Por fim, a revolução brasileira "ou será socialista ou não será revolução", frase que é repetida inúmeras vezes em documentos da organização.

O golpe e a ditadura militar exigiram da POLOP (como de toda a esquerda) respostas nos planos teórico e prático. Conhecer algumas dessas respostas pode nos aproximar daqueles militantes que as formularam, pois elas são, afinal, a sua voz. Neste caso, uma voz que emitia notas bastante dissonantes, trazendo maior complexidade harmônica à polifonia da esquerda. Três questões dirigiram a reflexão que está na origem dessa exposição: 1. como a POLOP caracterizou o golpe e a ditadura; 2. como ela concebeu o enfrentamento à ditadura; 3. como a ditadura afetou a POLOP. As duas primeiras questões serão desenvolvidas, nesta ordem, nas duas seções seguintes. A terceira, que não ensejou uma seção em separado, aparece na forma de considerações intervenientes em certas passagens do texto. Ao final pretendemos que a escuta da dissonância permita ao leitor avaliar por si mesmo os seus efeitos.

\footnotetext{
${ }^{2}$ Este texto, com pequenas alterações, foi originalmente publicado na coletânea organizada por MATTOS, Marcelo
} Badaró e VEJA, Rubén. Trabalhadores e Ditaduras. Brasil, Espanha e Portugal. Rio de Janeiro: Consequência, 2014. 


\section{O golpe e a ditadura vistos pela POLOP}

Bem antes do $1^{\circ}$ de abril de 1964 a possibilidade de um golpe de Estado foi antecipada por várias forças políticas e por intelectuais. Um editorial de dezembro de 1958 do Ação Socialista, órgão da Liga Socialista Independente (LSI), alertava para o risco de "restauração da ditadura bonapartista, desta feita, provavelmente, sob o império da espada." 3 O risco era mencionado em alguns documentos do PCB e constava no título de uma brochura publicada em 1962 pela Civilização Brasileira: Quem dará o golpe no Brasil? ? Poucos dias antes da queda de Goulart o jornal Política Operária convocava os trabalhadores para participar do comício da Central do Brasil com a chamada em primeira página: "frente de classe contra a ameaça de golpes." Não era adivinhação, era experiência prática: entre a queda de Vargas em 1945 (resultante, ela mesma, de um golpe) e a queda de Goulart em 1964 não faltaram tentativas concretas de derrubada de presidentes ou de impedimento à posse de eleitos, para não falar nos inúmeros episódios de propagação de boatos, nem todos fantasiosos, sobre a iminência de quarteladas, levantes ou golpes que não chegaram a se materializar. Após a renúncia de Jânio Quadros os indícios de que a ordem constitucional poderia ser derrubada ficaram ainda mais nítidos, mas foram interpretados de forma bem diferente pelo PCB e pela POLOP.

Para o PCB o perigo morava na pública e notória intolerância de segmentos conservadores para com o governo de João Goulart, indisposição que se manifestara desde a contestação à sua posse. A ameaça provinha, evidentemente, do imperialismo e de seus aliados internos e, por isso mesmo, tornava-se mais séria em face dos avanços da frente nacionalista, com cujo programa Jango, a despeito de sucessivas hesitações, parecia, enfim, comprometer-se. Apesar de tudo, aparentemente o PCB acreditava que o projeto golpista seria derrotado no nascedouro pela mobilização popular e também pelo fator dissuasório do "dispositivo militar", pois havia um setor da oficialidade que já teria dado provas de seu apreço à legalidade.

A POLOP pintava o quadro com cores um pouco mais sombrias e, de qualquer modo, desenhava um cenário muito diferente em sua tela. A probabilidade de ocorrer um golpe era maior, pois vinha de dois lados. Diferentes tendências políticas da classe dominante engendravam suas próprias alternativas golpistas: não apenas a direita, mas também o setor ligado a Jango que, através da "frente ampla", sonhava com poderes aumentados para o presidente, um "governo forte". Por isso a chamada do jornal falava em "ameaça de golpes", no plural. A POLOP iria ao comício para negar enfaticamente seu apoio a "qualquer golpe, venha de onde vier (...) seja da direita ou com aparências populistas" pois em ambos os casos os trabalhadores permaneceriam "em permanente estado de sítio, a mercê de maior exploração pela classe dominante."” Em qualquer dos dois casos, se viesse mesmo a acontecer, a ruptura institucional resultaria de uma opção política da própria classe dominante brasileira, mais especificamente da burguesia industrial, e não de uma reação movida contra ela pelo imperialismo e seus sócios.

\footnotetext{
3 "Frente Única Burguesa e Golpe Bonapartista". Ação Socialista, Ano I, no 1, dezembro de 1958. Publicado em SACHETTA, Hermínio. O Caldeirão das Bruxas e outros escritos. Campinas: Pontes-Edunicamp, 1992, p. 105. Da LSI participaram alguns dos marxistas que, anos depois, fundariam a POLOP.

${ }^{4}$ SANTOS, Wanderley Guilherme dos. Quem dará o golpe no Brasil? Rio de Janeiro: Civilização Brasileira, 1962.

5 Política Operária, n. 13, 12 de março de 1964, p. 1. Centro de Documentação e Memória da UNESP (doravante CEDEM), Fundo POLOP.

${ }^{6}$ A rigor no PCB houve quem cogitasse, nas teses preparatórias para o VI Congresso que circularam em março de 1964, a possibilidade também de um golpe "centrista". O estreitamento da aliança com Jango deve ter dissipado os temores, já que não teve consequência na política do partido. Ver PRESTES, Anita Leocádia. Luiz Carlos Prestes. O combate por um partido revolucionário. São Paulo, expressão Popular, 2012, pp. 97 ss.

7 "Os comunistas e a frente ampla". Política Operária, n. 13, ibidem, p. 1.
} 
Peço licença para uma pequena digressão, pois a ocasião é a mais oportuna. Um documento como este que acabo de citar cria problemas para a historiografia que vem se dedicando à missão de rotular a esquerda - ou a sua "cultura política" - como autoritária e até mesmo golpista. Esta é uma das peças do argumento que procura distribuir à direita e à esquerda cotas mais ou menos equivalentes de responsabilidade pela fragilidade da democracia no Brasil e, consequentemente, pelo golpe. Não é necessário fazer aqui a crítica dessa tese absurda que, entre outros equívocos sérios, não toma em consideração o acúmulo de reflexões sobre as formas autoritárias de que se revestem as relações de dominação nas condições históricas em que se desenvolveu a sociedade de classes no Brasil. $^{8}$ Basta, neste pequeno desvio de rota, assinalar que aquela historiografia sustenta suas conclusões num modo muito peculiar, para dizer o mínimo, de selecionar e ler as fontes. Resoluções muito famosas aprovadas naqueles anos em congressos do PCB sobre o caminho pacífico da revolução ou esta posição pública da POLOP contra qualquer golpe, "venha de onde vier", são ignoradas para que seja pronunciado sem perturbações o libelo acusatório contra a "esquerda golpista/autoritária". " O truque é velho mas ainda funciona, se não para engrandecer a pesquisa histórica, com certeza para credenciar seus autores a ocupar os lugares estratégicos que lhes são confiados por veículos da grande imprensa que não disfarçam seu ódio a tudo o que entendem ser "de esquerda".

Retornemos à POLOP e sua avaliação, singular na esquerda brasileira dos anos 60 , sobre o golpe como uma alternativa à disposição da classe dominante brasileira. Esta análise já estava completamente desenvolvida desde 1962, ano de publicação de O Caminho da Revolução Brasileira, brochura escrita por um dos teóricos de grande influência nos primeiros anos da organização, Luiz Alberto Moniz Bandeira. O livrinho circulou amplamente entre os militantes e permaneceu sendo usado em cursos de formação de quadros da POLOP mesmo depois do rompimento entre o autor e a organização, em 1965. Seu tema central não é o golpe, e sim as múltiplas faces da crise vertiginosa que afetava todas as dimensões da sociedade e que, por isso mesmo, demarcava o "caminho" que a revolução brasileira poderia tomar. O objetivo não era o de alertar ou preparar a militância para a eventualidade do golpe, mas caracterizar, na conjuntura, os elementos que determinavam os parâmetros concretos para o trabalho revolucionário a ser feito para que fosse aproveitada a oportunidade que a crise começava a abrir. A análise da crise, porém, mostrava que a classe dominante já andava, então, à procura do "seu Bonaparte"10.

O cenário teria adquirido contornos mais nítidos já a partir de agosto de 1961, por ocasião da renúncia de Jânio Quadros, interpretada como sintoma da crise profunda. Embora detivesse o controle sobre o Estado brasileiro, a burguesia industrial não dispunha de meios para enfrentar e superar os efeitos generalizados da crise que, nascidos dos impasses do desenvolvimento histórico do capitalismo no Brasil, se espraiavam por toda a sociedade. Recorrendo a dados econômicos abundantes, Moniz Bandeira procura demonstrar o aparecimento, no Brasil, de claros "sintomas de decrepitude" próprios da etapa monopolista do capitalismo, quando "a crise se institui como nota crônica, permanente."

\footnotetext{
${ }^{8}$ Iniciativas consistentes nesta direção podem ser lidas nos trabalhos reunidos por MELO, Demian Bezerra de (org.). A Miséria da Historiografia: uma crítica ao revisionismo contemporâneo. Rio de Janeiro, Conseqência, 2014. Também Marcelo Ridenti critica o uso anacrônico de certa concepção atual de democracia como parâmetro de julgamento de opções feitas no passado: RIDENTI, M. "Resistência e mistificação da resistência armada contra a ditadura: armadilhas para os pesquisadores". In: REIS, Daniel Aarão, RIDENTI, Marcelo e MOTTA, Rodrigo Patto Sá (orgs.) O golpe e a ditadura militar 40 anos depois (1964-2004). Bauru, Edusc, 2004, pp. 53-65.

9 VILLA, Marco Antônio. Ditadura à Brasileira - 1964-1985. A democracia golpeada à esquerda e à direita. São Paulo, Leya, 2014, p. 8.

${ }^{10}$ BANDEIRA, Moniz. O Caminho da Revolução Brasileira. Rio de Janeiro, MELSO, 1962, p. 38.

${ }^{11}$ BANDEIRA, Moniz. O Caminho... op. cit, p. 60.
} 
Dentre os fatores que anulavam a capacidade de reação da burguesia diante da crise, dois se destacariam. O primeiro tem a ver com a expansão do mercado interno, que permitiria incrementar a demanda e daria algum fôlego à acumulação bloqueada pela crise de superprodução. Nas condições brasileiras, tal expansão exigiria a reforma agrária e, justamente por isso, era impossível. A aliança com os fazendeiros era estratégica para assegurar à burguesia o comando político do país e, além disso, a mais tênue ameaça ao princípio da intocabilidade da propriedade privada era intolerável para as classes proprietárias em seu conjunto. Ora, recuando diante da exigência de remover o garrote sobre o mercado interno a burguesia mantinha sem solução um dos fatores cruciais da crise econômica.

O outro problema mais grave era a remessa de lucros, posto que ela rebaixava sistematicamente o volume de capital disponível para investimentos. Qualquer restrição ao envio para o exterior dos lucros das empresas estrangeiras, porém, representaria um conflito com o imperialismo, situação que a burguesia industrial (e não apenas os exportadores de gêneros agrícolas) precisava evitar. A razão é que o capital externo era o grande financiador da indústria. Ele estava inextricavelmente ligado ao processo de industrialização desencadeado no país e incrementado nos anos Vargas e JK. O próprio Estado, através da dívida pública, era prisioneiro da teia financeira do imperialismo. Portanto, um eventual acerto de contas com o imperialismo implicaria em "quebrar a máquina do Estado e romper a estrutura do capitalismo", efeitos absolutamente fora de cogitação para a burguesia brasileira. Moniz Bandeira considerava ilusório "querer antepor o capitalismo brasileiro ao imperialismo como se não compusessem o mesmo processo da economia mundial, com todas as suas contradições." ${ }^{12}$

$\mathrm{Na}$ raiz da instabilidade política que se manifestara agudamente em agosto de 1961 e que se prolongava pelos meses subsequentes estaria, portanto, a incapacidade da burguesia de dar solução aos impasses da acumulação de capital.

"A burguesia mostra-se impotente para atacar tanto o latifúndio quanto para rasgar as redes do imperialismo. Assiste à crise mundial do capitalismo, ao avanço da revolução operária e camponesa, à luta de libertação dos povos oprimidos e, por trás de si, tem um proletariado que, aparecendo também tardiamente no panorama histórico, assimilou a experiência de luta e as lutas do seu irmão europeu." 13

O bonapartismo passa a ser uma opção em momentos assim, quando "a burguesia perde a sua capacidade de exercer diretamente o governo e falta ao proletariado a vanguarda capaz de conduzi-lo ao poder." ${ }^{14}$ Nenhum setor da classe dominante estava em condições de impor sua solução para a crise e nem, por isso mesmo, de conquistar a unidade em torno de uma candidatura burguesa única. Jânio Quadros fracassou em seu intento de credenciar-se como árbitro bonapartista. João Goulart e sua política de conciliações não terá melhor sorte. "A burguesia necessita desembaraçar-se de todas as suas limitações. (...) Pede governo de força." 15

Por maior que fosse o risco de um golpe, Moniz Bandeira apostava suas fichas na saída revolucionária para a crise. Acreditando que a "revolução fermenta a olhos vistos"16 pois o capitalismo, no Brasil, já produzira seus próprios coveiros, Bandeira encerra seu livro em capítulos dedicados às questões que considera prioritárias: caráter e estratégia da revolução no Brasil, tática insurrecional ou via pacífica, em suma, o "caminho da revolução". Seu otimismo, como o de outras correntes de esquerda, chocou-se violentamente contra o muro em abril de

\footnotetext{
12 BANDEIRA, Moniz. O Caminho... op. cit. p. 32.

13 BANDEIRA, Moniz. O Caminho... op. cit. p. 34.

14 BANDEIRA, Moniz. O Caminho... op. cit. p. 38.

15 BANDEIRA, Moniz. O Caminho... op. cit. p. 40.

${ }^{16}$ BANDEIRA, Moniz. O Caminho... op. cit. p. 34.
} 
1964. Já a sua caracterização do golpe como uma iniciativa da classe dominante brasileira premida por uma crise que fugia ao seu controle, esta resistiu bem à prova e sobreviveu, em suas linhas gerais, nos documentos políticos da POLOP nos anos seguintes, em especial naqueles que tratavam de analisar o caráter do regime militar.

Informes e balanços políticos que foram produzidos pela direção da POLOP a partir de 1965 fazem referências ao golpe (às vezes chamado de "contrarrevolução") e à ditadura, mas sem maiores aprofundamentos. Pelo que pudemos descobrir no estado atual da pesquisa, o primeiro texto em que aparece uma análise sistemática e mais extensa do regime militar foi Classe e Estado, Ditadura e Democracia, escrito por Érico Sachs, que circulou em 1967 por ocasião dos acirrados debates preparatórios para o IV Congresso da Organização. O contexto daqueles debates era de intensificação da luta interna que terminaria por levar a organização ao "racha" (em pleno congresso desligaram-se da POLOP quase metade dos delegados que, posteriormente, se organizariam como Comandos de Libertação Nacional - COLINA - e Vanguarda Popular Revolucionária -VPR). Uma das questões postas na disputa interna de 1967 dizia respeito à bandeira de luta pelas liberdades democráticas, defendida por alguns militantes e contestada por outros que a interpretavam como a defesa do retorno ao regime pré-golpe, isto é, à democracia burguesa. Veremos que essa questão permanecerá na agenda da POLOP por alguns anos. Aqui importa registrar que, mesmo sem ter a urgência da questão da guerrilha, o tema estava na pauta e havia se tornado suficientemente importante para que Érico Sachs, um teórico e dirigente maior na Organização, preparasse uma intervenção mais elaborada sobre o caráter da ditadura como forma particular do Estado burguês.

A interpretação do regime militar realizada por ele retoma teses clássicas do marxismo sobre o Estado e também recupera aspectos das análises de August Thalheimer sobre o fascismo europeu. Pouco conhecido no Brasil, Thalheimer tinha sido dirigente do Partido Comunista Alemão (KPD) nos anos 20, ao lado de Heinrich Brandler. Ambos romperam com o stalinismo em princípios dos anos 30 e fundaram o Partido Comunista Alemão - Oposição (KPD-O). Em vários outros escritos de Érico Sachs são empregados conceitos e formulações teóricas de Thalheimer, especialmente sobre o fascismo e o imperialismo. ${ }^{17} \mathrm{O}$ texto de Sachs começa, não por acaso, pela democracia, descrita, a partir de citações de Lênin, como uma modalidade de Estado burguês, uma "organização criada para a aplicação sistemática da violência de uma classe contra outra" 18 . Seria, na verdade, o tipo mais avançado e perfeito de domínio burguês, por duas razões. Nela o poder é exercido diretamente pelos representantes da burguesia nos parlamentos e nos governos, espaços assegurados pelo poder econômico. Além de ser um governo direto da burguesia, a democracia traz uma segunda característica, igualmente valiosa, que é o disfarce do caráter de classe do poder do Estado, que fica escondido por detrás de procedimentos democráticos como eleições e debates parlamentares. Ditadura de classe, como todo Estado, a democracia se caracterizaria por ser direta (exercida por quadros políticos burgueses sem intermediários) e velada (ocultando sua verdadeira natureza de dominação de classe).

Sachs enfatiza a lembrança de que tal caracterização da democracia, formulada pelos clássicos do marxismo, foi abandonada pelos reformistas que passaram a apostar na ocupação de espaços no Estado democrático burguês visando a transição pacífica ao socialismo. Os revolucionários, leninistas, sempre combateram tais ilusões, embora reconhecessem que a liberdade de

\footnotetext{
17 Textos de Thalheimer sobre o fascismo foram publicados, com uma apresentação de Érico Sachs, pela revista editada pelos militantes da POLOP no exílio, Marxismo Militante Exterior, números 1 e 2 (1975 e 1976, respectivamente).

18 SACHS, Eric. "Classe e Estado, Ditadura e Democracia”. In: MIRANDA, Orlando e FALCÓN, Pery (orgs.). POLOP: uma trajetória de luta pela organização independente da classe operária no Brasil. $2^{\mathrm{a}}$ Ed., Salvador, Centro de Estudos Victor Meyer, 2010, p. 73. O trecho entre aspas é uma citação feita por Sachs de O Estado e a Revolução, de Lênin.
} 
organização e ação, maior na democracia do que em regimes fechados, é um fator que não se pode negligenciar.

As vantagens da democracia para a burguesia podem, todavia, desaparecer em certas conjunturas: "Quando os recursos da democracia burguesa não garantem mais a ordem existente e os privilégios das classes dominantes, estas escolhem o caminho da ditadura aberta." 19 Desenvolvendo as sugestões de Thalheimer, Sachs descreve três formas assumidas, em diferentes quadras históricas, por ditaduras abertas (e indiretas) da burguesia. A primeira e mais conhecida foi o bonapartismo, estudado pelo próprio Marx no livro O 18 Brumário de Luis Bonaparte. Ameaçadas pelos graves efeitos de uma crise econômica e política que não podiam controlar, as diferentes facções da burguesia francesa entregaram o poder a Luís Bonaparte em troca da repressão aberta contra as massas populares. Agindo deste modo os burgueses sacrificaram seus partidos políticos e seus representantes parlamentares, privando-se dos instrumentos imediatos do poder. O bonapartismo "entrou na história como ditadura aberta, mas indireta, da burguesia, num momento em que o proletariado, apesar de assustar e intimidar a classe dominante, ainda não representava uma ameaça real à existência da sociedade." ${ }^{20}$ Sustentado pelo campesinato conservador e guarnecido pela bizarra Sociedade 10 de Dezembro, o bonapartismo serviu, a seu modo, à "cúpula das classes dominantes", isto é, grande indústria e latifundiários aburguesados que já não conseguiam governar pelos meios parlamentares instituídos após a revolução de 1848.

A segunda forma de ditadura aberta e indireta da burguesia mencionada por Sachs é o fascismo. Seria a continuação da experiência bonapartista, mas em condições históricas alteradas pelo desenvolvimento do próprio capitalismo. O fascismo ocorre em países capitalistas desenvolvidos como "reação direta ao movimento político e sindical da classe operária - geralmente às tentativas fracassadas de revolução proletária ou como reação às decepções de uma prolongada prática reformista." A burguesia para a qual o fascismo governa é diferente daquela estudada por Marx: "trata-se dos expoentes do capital financeiro e dos grandes monopólios da época do imperialismo." O ponto de apoio do fascismo é a pequena-burguesia que, ameaçada em sua existência material, gira radicalmente à direita. São pequeno-burgueses os quadros mais atuantes (inclusive as milícias) e a ideologia fascista, "uma mistura de nacionalismo, anticapitalismo popular e um messianismo misticista." ${ }^{21}$

Por fim o texto trata das ditaduras militares. Elas são descritas como um recurso imediato à disposição da classe dominante, ao contrário do bonapartismo ou do fascismo que, sendo fenômenos mais complexos, levam tempo para amadurecer. Por isso mesmo as ditaduras militares são mais frequentes, particularmente na América Latina. No longo prazo, porém, elas "não correspondem propriamente aos anseios da burguesia." Ditaduras prolongadas seriam típicas de países ainda dominados por "velhas oligarquias do campo", não de países industrializados ou em processo de industrialização: "Os problemas de uma sociedade capitalista moderna são demais para uma ditadura militar, com seu imobilismo, conservadorismo e seu código de continências." 22

No Brasil, segundo Sachs, ocorreram experiências com quase todas as formas de ditadura burguesa, veladas (e diretas) e abertas (e indiretas): bonapartismo com Vargas (apoiado não na pequena burguesia rural, mas na jovem e inexperiente classe operária de origem rural), tendências fascistas com o Integralismo, democracia burguesa entre 1945 e 1964 (com acidentes

\footnotetext{
${ }^{19}$ SACHS, Eric. "Classe e Estado, Ditadura e Democracia”. In: MIRANDA, Orlando e FALCÓN, Pery (orgs.). POLOP: uma trajetória... op. cit. p. 76

${ }^{20}$ SACHS, Eric. "Classe e Estado, Ditadura e Democracia”... op. cit. p. 77.

${ }^{21}$ SACHS, Eric. "Classe e Estado, Ditadura e Democracia”... op. cit. p. 78.

22 SACHS, Eric. "Classe e Estado, Ditadura e Democracia”... op. cit. p. 79.
} 
institucionais no percurso e em aliança com o latifúndio) e, finalmente, a ditadura militar. A hipótese de que a ditadura militar não teria fôlego para se prolongar por muitos anos, sugerida acima, ecoava em outras passagens do texto. A burguesia brasileira saudou o golpe e o "governo forte" que a protegia das "aparições das massas reprimidas", mas "um Executivo que governava à base de coronéis dos IPMs não resolvia os seus problemas". Castelo Branco "não conseguiu encontrar um denominador comum para satisfazer as facções da classe dominante."23

Algumas questões que emergem da leitura deste documento terão de ser enfrentadas em outro momento: havia mesmo um setor da POLOP, Sachs incluído, que acreditou que a ditadura teria vida curta? Qual o significado dessa polêmica no contexto da luta interna daqueles anos? Supondo que tenha sido defendida essa tese, como seus proponentes e apoiadores lidaram com a constatação, que não tardou, de que a ditadura se estenderia por um período bem mais longo do que eles previram? Respostas para perguntas como essas permitirão observar muito mais de perto a vida real da organização, a montagem da política como vivência histórica, construção militante forjada no fogo do debate e da prática. Por enquanto ainda temos de tratar do primeiro problema que nos propusemos - conhecer a caracterização que a POLOP fez do golpe e da ditadura - no plano mais geral, que é aquele a que temos acesso a partir de documentos como textos de dirigentes, teses ou resoluções.

Mesmo nesse nível, apesar de tudo, chegamos a resultados interessantes. Sachs registra que, como toda ditadura indireta, o governo Castelo Branco "conseguiu uma liberdade de ação muito maior em relação às aspirações imediatas das facções da classe dominante do que qualquer outro governo desde o Estado Novo". Apenas a "cúpula da classe dominante, as grandes indústrias e os monopólios" estavam em condições de influir, de algum modo, nas decisões governamentais mas, ao mesmo tempo, a ditadura livrou a burguesia industrial de sua dependência política perante o latifúndio (cujos votos perderam importância). O Executivo podia, assim, "seguir uma política a longo prazo de consolidação da sociedade exploradora em bases modernas, isto é, uma política de concentração de capitais, de racionalização da indústria e do fortalecimento dos monopólios, que está ligada ao nome de Roberto Campos" ${ }^{24}$. Na medida em que este processo, imposto de cima, cria atritos no seio da própria burguesia abre-se o espaço para o surgimento de uma oposição burguesa que, sem contestar diretamente o golpe ou a ditadura, queixa-se da política econômica que não atende suas necessidades imediatas.

Ainda mais interessante, como voz dissonante no campo da esquerda, é o arremate do texto. Ao contrário de análises que qualificam o governo militar como "pró-imperialista", Sachs adverte:

“... não devemos nos enganar quanto ao caráter de classe do Estado brasileiro. As suas bases de classe se encontram no país. A política nacional, em última instância, é feita aqui. (...) O Estado, o governo, são expoentes das classes existentes no país - concretamente, são sustentáculos e instrumentos de nossas classes dominantes. A influência do imperialismo no país, as posições que conquistou, devem-se unicamente às atitudes da nossa burguesia que lhe abriu as portas, que diariamente clama pela vinda de capitais estrangeiros e que está associada ao imperialismo mundial, especialmente o norte-americano". ${ }^{25}$

Esta análise sobre o caráter de classe da ditadura, ou pelo menos sua linha teórica central, calou fundo no debate na esquerda brasileira. Voz dissonante, quando formulada, terminou por exercer uma influência considerável até sobre organizações que percorreram trajetórias muito diferentes da POLOP. O mesmo ocorreu com a caracterização do Brasil como país capitalista e,

\footnotetext{
${ }^{23}$ SACHS, Eric. “Classe e Estado, Ditadura e Democracia”... op. cit. p.83.

${ }^{24}$ SACHS, Eric. "Classe e Estado, Ditadura e Democracia”... op. cit. p. 83-4.

${ }^{25}$ SACHS, Eric. “Classe e Estado, Ditadura e Democracia”... op. cit. p. 84.
} 
consequência dessa premissa, a determinação do caráter socialista da revolução. Paradoxalmente, mesmo quando algumas de suas principais teses começaram a ser incorporadas por outras correntes políticas, a POLOP continuava a ser minoritária no campo da esquerda. É possível que esta situação tenha algo a ver com a política traçada para enfrentar a ditadura, que é o nosso próximo tema.

\section{A POLOP e o enfrentamento da ditadura.}

A caracterização da ditadura militar estabelecia a plataforma teórica sobre a qual foram montados os dispositivos de intervenção política da POLOP. A luta contra o regime militar foi concebida como luta contra o Estado burguês em uma de suas formas, ou seja, a tática (política para enfrentar a ditadura) se demarcava no território político delimitado pela estratégia da revolução socialista. A discussão do projeto estratégico foi uma das prioridades da organização em seus primeiros anos e teve seu clímax em setembro de 1967, no IV Congresso, com a aprovação do Programa Socialista para o Brasil. Quando se tratava de lidar com os problemas práticos postos na ordem do dia pela dinâmica da luta política, no entanto, a POLOP teve de produzir respostas para questões mais imediatas e concretas. Se a orientação geral de sua política decorria da caracterização da ditadura como forma de Estado burguês e da interpretação da luta na perspectiva da estratégia socialista, a intervenção dos militantes em cada situação concreta exigia elaboração tática. Foi esse esforço de elaboração que produziu os documentos que analisaremos a seguir.

Outra vez nos deparamos com os limites atuais da pesquisa. Por mais privilegiados e ricos que sejam tais documentos e por mais que eles orientem de fato o trabalho político dos militantes, a elaboração de programas e resoluções é apenas parte da vida de uma organização. A história da esquerda não se esgota na recuperação de suas teses, sua linha política, suas formulações programáticas. A intervenção política real acontece na ação cotidiana dos militantes junto a suas bases e esferas de atuação e essa história, para ser conhecida, requer outra documentação, vinculada àquela atividade prática: jornais, boletins, panfletos e outros materiais de agitação e propaganda através dos quais a organização atuava concretamente. Tudo isso e mais os acervos guardados nas memórias dos militantes, tesouro inestimável que corre risco crescente de perda definitiva. Teremos de aguardar um pouco mais para dar conta dessa dimensão da história da POLOP.

Dispomos, contudo, de resultados significativos obtidos do exame de documentos em que os problemas táticos foram enfrentados no plano teórico. Emergem desses documentos outras notas dissonantes emitidas pela POLOP. Dentre os temas que se impuseram, incontornáveis, à POLOP e a todas as organizações de esquerda que se envolveram nas lutas contra a ditadura selecionamos dois para análise: a questão do foco guerrilheiro, tema central em qualquer debate sobre tática até o início dos anos 70, e o papel da esquerda revolucionária no contexto da crise da ditadura e da transição política, assunto obrigatório a partir da segunda metade da década de 70 . A preferência por esses temas se justifica não somente pela importância que tiveram para todas as correntes da esquerda, mas porque permitem por em relevo algumas das características que singularizavam a POLOP no meio delas.

Quanto à guerrilha, o posicionamento da POLOP sofreu algumas mudanças ao longo dos anos. Num primeiro período, compreendido entre o pós-golpe e os últimos anos da década de 60, o foco guerrilheiro é considerado necessário e a ele é dedicada atenção frequente nos documentos da organização. Em janeiro de 1965 a prioridade era superar a dispersão gerada pelo golpe, que atingiu a POLOP com prisões, inclusive de dirigentes, logo nos primeiros meses. Com o objetivo 
de preparar a organização para atuar sob as novas condições impostas pela ditadura a direção emite uma "Orientação interna" em janeiro de 1965, e nela a guerrilha já é abordada. Os "métodos clássicos de mobilização popular" estavam fora de cogitação em face da repressão, obrigando os revolucionários a investir nos "métodos conspirativos, o que limita o raio de ação dos militantes, mas garante a continuidade da luta" ${ }^{26}$ Nada de abandonar a prioridade do trabalho político junto à classe operária, questão de honra reafirmada em todos os momentos da trajetória da organização. O terreno essencial em que esse trabalho teria de ser feito era, portanto, a classe operária: conselhos e comitês de fábricas, construídos no espaço deixado pelo desmantelamento das cúpulas sindicais reformistas, seriam a base da criação de núcleos revolucionários.

O objetivo da esquerda revolucionária era derrubar a ditadura pela via insurrecional, mas para isso seria necessário "desintegrar e desgastar o instrumento principal da opressão - as forças armadas" e também "armar os trabalhadores", condições ausentes no Brasil. Ora, essas duas tarefas só poderiam ser cumpridas pela "guerra de guerrilhas", cuja característica mais importante era precisamente a de "iniciarem-se com pequenas forças que crescem enfraquecendo a máquina militar e transformando-se na vanguarda combatente das classes exploradas" 27 . Não se trata, desde aqui, de uma visão puramente militarista da guerrilha. Ela despertaria a confiança das massas através da "autoridade conquistada na luta armada" e, por se desenrolar no campo, elevaria a nível superior a luta camponesa e destruiria um dos pilares da reação - o latifúndio. Nos termos da "Orientação": "Por isso, ao lado de sua significação especificamente militar, o foco armado tem hoje um papel fundamentalmente político, como fomentador e orientador da luta revolucionária dos trabalhadores da cidade e do campo."28

Por outro lado o documento reafirma explicitamente a necessidade de "construção da vanguarda organizada em aparelho partidário". ${ }^{29}$ Então temos uma orientação que aponta para o foco guerrilheiro mas também para a insurreição, que não abre mão do trabalho nas fábricas e nem do papel do partido de vanguarda. A busca de equilíbrio entre esses três elementos marcou a elaboração da POLOP nesta fase.

Escrevendo no contexto de seu rompimento com a Organização, em 1976, Raul Villa (pseudônimo de Eder Sader) avaliou o projeto de guerrilha daqueles anos como sendo dirigido pela "típica ingenuidade voluntarista do foquismo, que espera o desenvolvimento espontâneo das massas, teleguiado por sua vanguarda iluminada." ${ }^{30} \mathrm{O}$ teor do documento que acabamos de ver não confirma esta avaliação: fala-se em organizar núcleos e comitês, não em espontaneidade das massas; a vanguarda está por ser construída, não como algo dado. Villa menciona outros aspectos que merecerão, no futuro, um olhar mais detido, entre os quais a conexão entre o projeto de foco da POLOP e a movimentação, no mesmo sentido, de grupos ligados a Leonel Brizola ou as medidas práticas, tomadas pela Organização, para montar seu setor militar. Seu julgamento negativo do "voluntarismo foquista", contudo, deve ser lido como o que é: o balanço feito por alguém que precisava justificar sua decisão de afastar-se da organização. Nem se pode esquecer que ele foi escrito num momento em que a experiência guerrilheira já havia sido completamente derrotada e não eram poucos os militantes que seguiam o caminho do arrependimento. Há, de qualquer modo, outros documentos em que podemos ver como a Organização concebia o foco guerrilheiro.

\footnotetext{
26 Orientação Interna, janeiro de 1965, mimeo, p. 1. CEDEM, Fundo POLOP.

27 Orientação Interna... op. cit. p. 1.

${ }^{28}$ Orientação Interna ... op. cit. p. 2.

29 Orientação Interna... op. cit. p. 2.

${ }^{30}$ VILLA, Raul (Eder Sader). Para um balanço da P.O. Brasil Socialista, ano II, n. 7, outubro de 1976, p. 12.
} 
Entre 1966 e 1967 circulou por toda a Oganização uma série de quatro textos longos e densos de análise política, intitulados Aonde Vamos? que eram assinados pela Comissão Nacional mas escritos, efetivamente, por Érico Sachs. No conjunto, os textos podem ser lidos como mais um esforço teórico para equilibrar os elementos acima mencionados. Nos três primeiros a atenção é dedicada ao balanço da atuação da esquerda no país, incluindo a própria POLOP, com ênfase no problema da organização independente do proletariado (Texto 1); à análise das condições materiais que favoreceram o predomínio do reformismo no proletariado brasileiro (Texto 2); à discussão pormenorizada do conceito de governo de transição, base para a proposição tática do governo revolucionário dos trabalhadores (Texto 3). Somente no quarto texto, que tem o subtítulo "Foco e revolução", a guerrilha é discutida.

Nem por isso se deve pensar que havia qualquer hesitação no reconhecimento da necessidade da guerrilha: "A forma de luta armada que está em foco, e que está hoje dentro de um raciocínio estratégico e tático, é a guerra de guerrilha." 31 Havia, sim, ressalvas contra

"certas generalizações que, de um lado, apresentam essa forma de luta como arma milagrosa, que resolve definitivamente o problema da luta revolucionária em todas as circunstâncias e, de outro, generaliza os métodos de luta de determinadas guerrilhas, em determinadas condições históricas, tanto no que diz respeito à sua tática militar, quanto aos aspectos políticos da luta." 32

O documento assinalava ainda que a guerrilha sozinha é insuficiente para vencer tropas regulares. Estas somente podem ser batidas por outro exército, como ocorreu na China, em condições que incluíam a ocupação do país por tropas estrangeiras, ou por um ato insurrecional da classe trabalhadora, como a greve geral que permitiu a vitória dos guerrilheiros em Cuba.

Ressalvas à parte, o texto analisa a experiência guerrilheira na América Latina e na China e discute várias questões propriamente ligadas à construção do foco, sempre a partir do pressuposto leninista de que a guerra, mesmo de guerrilhas, é a continuação da política. Prevalece, portanto, a premissa de que "não podemos encarar o problema da luta armada insurrecional isolado do contexto geral das lutas de classe." ${ }^{33} \mathrm{Um}$ dos problemas analisados é o da preparação política. O essencial não seria a preparação local, entendida como trabalho político com as populações rurais na zona escolhida para o foco, e sim a preparação das classes para a luta que está para iniciar. Aliás, diante da vigilância anti-guerrilha em alerta em toda a América Latina após a revolução cubana, fazer a guerrilha dependente do trabalho político local prévio seria apenas pretexto para adiá-la "para o dia do juízo final" 34 . Uma das garantias do foco é justamente a sua mobilidade, sendo ilusório apostar em "bases guerrilheiras" ou "zonas liberadas" que, nas fases iniciais da luta, apenas deixariam a guerrilha à mercê das forças mais poderosas da repressão. Por outro lado, estabelecer "um novo ascenso do movimento de massa como condição para a criação de focos (...) equivale a um anti-guerrilheirismo envergonhado" 35 .

Outra questão examinada é a da relação guerrilha-partido, que a esquerda abordava em termos de precedência de um ou outro dos polos. A direção da POLOP propunha outra maneira de colocar o problema, partindo das condições concretas da luta no Brasil. Um foco guerrilheiro só estaria à altura de sua missão, que não é puramente militar mas também de intervenção política na luta de classes, na medida em que fosse constituído com "concepções políticas claramente

\footnotetext{
31 SACHS, Erico. Aonde Vamos? Parte IV, julho de 1967, mimeo, p. 1. CEDEM, Fundo POLOP.

32 SACHS, Erico. Aonde Vamos? Parte IV ... op. cit. p. 2.

33 SACHS, Erico. Aonde V amos? Parte IV ... op. cit. p. 1.

${ }^{34}$ SACHS, Erico. Aonde V amos? Parte IV ... op. cit. p. 6.

${ }^{35}$ SACHS, Erico. Aonde Vamos? Parte IV ... op. cit. p. 6.
} 
definidas e com objetivos políticos claramente delineados" ${ }^{36}$. Esse trabalho de "esclarecimento teórico" prévio pressupõe a existência de uma vanguarda, mas ela não precisaria necessariamente existir na forma acabada de um partido. De fato, nas condições de repressão vigentes, um partido revolucionário poderia ser, no máximo, de quadros. É justamente a guerrilha, pela propaganda prática e armada, que poderia transformar a vanguarda em partido.

A POLOP introduziu a guerrilha em sua concepção sobre o caminho da luta revolucionária no Brasil, mas não abriu mão de suas formulações anteriores e nem, logo veremos, das que estavam em elaboração no mesmo ano em que circulou o Aonde V amos parte IV: "temos de enquadrar o problema da guerrilha no quadro geral da luta de classes no País. A guerrilha não pode substituir a luta de classes. Tem de fomentá-la, aguçá-la, tem de polarizar as forças existentes" ${ }^{\prime 37}$. A revolução no Brasil deveria passar pelo governo de transição dos trabalhadores da cidade e do campo, articulado por uma Frente de Trabalhadores da Cidade e do Campo. O caráter da revolução é socialista, o proletariado é seu núcleo dirigente. A guerrilha teria de enquadrar-se aí.

De acordo com esta concepção, caberia às classes urbanas a iniciativa e a decisão final da luta de classes no Brasil, mas a revolução passaria necessariamente pelo campo. A guerrilha deveria nutrir-se das aspirações de camponeses, posseiros, trabalhadores rurais que são sua condição de sobrevivência. Mas só teria chance de vencer se apelasse para o proletariado urbano, para a sua consciência de classe:

“Apelar para o proletariado significa apelar para sua consciência de classe, encorajar a luta dentro da fábrica, dentro da indústria, dentro das cidades contra o Estado burguês, contra a burguesia em aliança com o imperialismo. E apelar para os métodos tradicionais de luta revolucionaria do proletariado, a fim de prepará-lo para os métodos não tradicionais." ${ }^{38}$

Essas são tarefas que os marxistas atribuem, geralmente, ao partido revolucionário, e a POLOP reconhece isso no próprio texto. No entanto, como tal partido não existia no Brasil (só as vanguardas, como a própria POLOP), era a guerrilha que poderia cumprir este papel: "E nesse sentido não há dúvida que a guerrilha em parte, preenche o vácuo da não existência de um partido revolucionário. Em parte, e por certo prazo...". Tais posições, no entanto, não eram consensuais no interior da Organização.

O ano de 1967 foi agitado para a POLOP. A preparação do IV Congresso se deu em meio à intensificação da luta interna e o tema da guerrilha era a questão mais aguda. Quando ocorreu o congresso, em setembro, a guerrilha foi a razão principal para a cisão. Em sua "Carta aberta aos revolucionários", os militantes (a maioria de Minas Gerais) que rompiam com a POLOP recusavam a tese da precedência das classes urbanas e afirmavam que "a luta armada - como forma fundamental da luta de classes no atual período - terá de ser centralizada no campo, na forma de guerra de guerrilhas". ${ }^{40} \mathrm{E}$ sem vacilações: "Para nós a tarefa fundamental e imediata é a instalação do foco guerrilheiro, não como mero apêndice, mas como núcleo do Partido e embrião do Exército Popular". O texto era concluído com a adesão à Declaração da Conferência da OLAS "ignorada pela direção da POLOP e impedida de ser discutida" e assinado pelos "revolucionários que rompem com a POLOP". ${ }^{41}$ Quase a metade dos delegados (14 contra 16) posicionou-se contra a direção nacional a respeito da mais importante questão do congresso: a aprovação do Programa Socialista para o Brasil (PSpB), documento que finalmente sistematizava de

\footnotetext{
${ }^{36}$ SACHS, Erico. Aonde Vamos? Parte IV ... op. cit. p. 6.

${ }^{37}$ SACHS, Erico. Aonde V amos? Parte IV ... op. cit., p. 7, grifado no original.

38 SACHS, Erico. Aonde V amos? Parte IV ... op. cit., p. 8.

${ }^{39}$ SACHS, Erico. Aonde V amos? Parte IV ... op. cit. p. 8.

${ }^{40}$ Carta aberta aos revolucionários. Setembro de 1967, mimeo, p. 1. CEDEM, Fundo POLOP.

${ }^{41}$ Carta aberta aos revolucionários... op. cit.p. 2.
} 
forma ampla e minuciosa a concepção sobre a revolução socialista no Brasil que a POLOP vinha desenvolvendo desde sua origem. Após aquele setembro, a POLOP não seria mais a mesma. A rigor, nem seria mais POLOP.

Os que se mantiveram na organização buscaram aproximar-se de outros grupos de esquerda, em particular a Dissidência Leninista do Rio Grande do Sul, dando origem ao Partido Operário Comunista (POC) que fez seu congresso de fundação em abril de 1968. As bases programáticas do POC eram as mesmas defendidas pela direção da POLOP e atacadas pelos dissidentes, inclusive sobre a guerrilha: "combinar a GUERRA DE GUERRILHAS no campo com a INSURREIÇÃO OPERÁRIA nas cidades" "42. De fato, o POC assimilou na íntegra o PSpB que, quanto à guerrilha, mantinha-se na perspectiva do Aonde Vamos e da Orientação Política de 1965. Naquele documento o foco guerrilheiro é reafirmado por mais de uma razão, inclusive por permitir manter a luta por longo tempo, mesmo nas fases de descenso do movimento de massas. O papel do foco, como nos textos anteriores, envolveria mais do que objetivos militares: "Realizando desde o início, em miniatura, a Frente Revolucionária dos Trabalhadores da Cidade e do Campo, a guerrilha potencializará a vOz da vanguarda clandestina em todo o país, preparando o reagrupamento das forças das classes revolucionárias para a luta final." Por fim, o "fato consumado do foco de guerrilha elevará o nível da luta, apressará a unificação das forças da esquerda revolucionária e a constituição do partido revolucionário da classe operária." ${ }^{43}$

Um tema que dividiu a POLOP ao meio e que, de qualquer modo, seguia na ordem do dia em função da atração que exercia sobre toda a esquerda, tinha de se tornar prioridade. Em 1968 Érico Sachs, escrevendo sob pseudônimo, publicou uma longa análise do livro de Régis Debray, Revolução na Revolução, que exercia enorme influência sobre amplos segmentos da esquerda no Brasil e na América Latina. O eixo da visão da POLOP sobre o foco era mantido, mas a crítica subia de tom. Após registrar solidariedade com Debray, que se encontrava preso na Bolívia, Sachs não poupa munição. Considera o autor um revisionista, acusa-o de secundarizar o papel do partido e de ter subordinado as exigências da luta de classes ao objetivo de formar vanguardas político-militares de caráter pequeno-burguês: "Toda uma argumentação ideológica e programática da guerrilha latino-americana está sendo adaptada ao nível e às necessidades dessa camada radical da classe média, inclusive fórmulas que não constaram na guerrilha cubana (luta de libertação nacional, Exército Popular, etc.)". ${ }^{44}$

Em 1970 Érico Sachs voltou a tratar da guerrilha, mas agora sob uma perspectiva diferente. Naquele momento rompiam com o POC a maioria dos militantes da POLOP que o haviam fundado, e procuravam se reagrupar sob o nome de Organização Comunista Marxista-Leninista Política Operária (OCML-PO). Pelo que sabemos até o momento, Érico Sachs, afastado da direção e exilado no México, não participou diretamente das discussões que levaram ao "racha". Mesmo assim seu papel como teórico e dirigente era incontestável, o que explica a ampla circulação do seu Caminho e Caráter da Revolução Brasileira, assinado pelo pseudônimo Ernesto Martins. No longo texto o "velho", como começava a ser chamado, revisitava vários problemas atinentes à revolução socialista na fase imperialista e no contexto latino-americano e brasileiro, em particular. Sobre o foco, a novidade é que ele é descartado como alternativa viável nas condições da luta revolucionária no Brasil.

\footnotetext{
${ }^{42}$ Resolução Política do Congresso de Fundação do Partido Operário Comunista. Abril de 1968, mimeo, p. 2. CEDEM, Fundo POLOP, maiúsculas no original.

43 "Programa Socialista para o Brasil". In: MIRANDA, Orlando e FALCÓN, Pery (orgs.). POLOP: uma trajetória de luta pela organização independente da classe operária no Brasil. Op. cit., p. 128.

${ }^{44}$ MARTINS, Ernesto (Erico Sachs). “Luta armada e luta de classes”. Marxismo Militante, I, 1, 1968, p. 28.
} 
A premissa do texto deriva da caracterização do regime feita pela POLOP: a ditadura havia mudado as condições de luta, mas não alterou o problema fundamental do processo revolucionário no Brasil. Este problema continuava a ser o da formação do proletariado como classe para si, a conquista de sua independência ideológica e política, tarefa que não poderia ser realizada sem a "atuação consciente e contínua de um agente da história, a vanguarda revolucionária". Por isso a POLOP "subordinou todos os aspectos da luta de classes, o estudantil, o do campo, a luta armada e sua forma particular de guerra de guerrilha, ao objetivo estratégico da mobilização e organização do proletariado industrial." ${ }^{\prime 5} \mathrm{O}$ trabalho político junto à classe e à nova esquerda emergente (sobretudo dissidências do PCB) chegou a produzir resultados, como nas greves de Contagem e Osasco em 1968, mas o endurecimento do regime no final daquele ano trouxe novas dificuldades. O movimento refluiu muito e foi então que

"os novos revolucionários escolheram objetivos mais imediatos e sua concepção de luta armada os fez desertarem do trabalho nas fábricas. A consequência geral foi a liquidação, destruição e desaparecimento de grande parte das organizações operárias construídas nos últimos dois anos (...) O "marxismo-leninismo" da maioria da nova esquerda não teve muito fôlego." ${ }^{36}$

Depois de recuperar a compreensão que os clássicos do marxismo tinham sobre o papel revolucionário da classe operária, Sachs aponta sua arma da crítica para os erros dos grupos de esquerda que, ao seguirem para a luta armada, desertaram da classe. O PCdoB é criticado pela concepção de revolução nacional e democrática, por considerar que o problema chave da revolução brasileira é a questão camponesa e, consequentemente, por desprezar o trabalho nas cidades e fábricas. As organizações mais influenciadas pelo "debraysmo" teriam em comum o desprezo ao partido, substituído, em nome da luta armada, pela vanguarda militar às vezes denominada Comando Político-Militar. Sachs dedica atenção especial às posições sustentadas por Carlos Marighella cuja morte, em novembro de 1969, não é mencionada no texto. Apesar de proclamações protocolares feitas em linguagem marxista, Marighella não superaria a indefinição quanto ao papel da classe operária. Do mesmo modo, apesar da "profissão de fé da luta pela revolução socialista" 47 que Marighella e a ALN fizeram tardiamente, na luta prática o socialismo seria subordinado à libertação nacional. Daí sua ênfase no protagonismo das classes médias, consideradas como estando entre as forças mais combativas, desconsiderando a heterogeneidade que as constitui. Sachs cita um documento de Marighella em que, ao lado dos camponeses e do proletariado, as classes médias são vistas em oposição às classes dominantes e empenhadas na libertação nacional. ${ }^{48}$

A crítica vai mais longe ainda. A estratégia de Marighella não se desenvolveria pelos espaços da luta de classes e nem sequer partiria do estudo das experiências de luta de classes na América Latina ou da análise da luta de classes no Brasil. Tratar-se-ia de "uma estratégia construída à base de premissas subjetivas. Da premissa de ser a ação do revolucionário que cria a situação revolucionária." ${ }^{49}$ Tal subjetivismo é estranho ao marxismo, como o demonstram as lutas de Marx contra os que queriam fazer insurreições a qualquer custo, como Schapper, na Liga dos Comunistas, ou Bakunin, na I Internacional, ou o combate de Lênin contra os narodniki. Para os marxistas, os revolucionários "não criam as situações revolucionárias e não faz̧em as revoluções."

\footnotetext{
45 MARTINS, Ernesto (Erico Sachs). "Caminho e Caráter da Revolução Brasileira". In: MIRANDA, Orlando e FALCÓN, Pery (orgs.). POLOP: uma trajetória de luta pela organização independente da classe operária no Brasil. Op. cit., p. 166.

46 MARTINS, Ernesto (Erico Sachs). "Caminho e Caráter da Revolução Brasileira”... op. cit., p. 168.

${ }^{47}$ MARTINS, Ernesto (Erico Sachs). "Caminho e Caráter da Revolução Brasileira”... op. cit. p. 176.

48 O documento citado é Operações e táticas de guerrilhas.

${ }^{49}$ MARTINS, Ernesto (Erico Sachs). Caminho e Caráter da Revolução Brasileira... Op. cit., p. 179.
} 
O que eles fazem é "aproveitar as situações revolucionárias que a própria sociedade produz (...) na medida em que souberem mobilizar e dirigir a classe revolucionária para preencher o seu papel." 50

Ora, a situação do Brasil naqueles anos finais da década "de maneira nenhuma pode ser considerada revolucionária. Ao contrário, o país saiu da crise econômica cíclica." Como não leva nada disso em consideração,

"Marighela declarou guerra revolucionária na cidade e no campo. O resultado foi um confronto direto entre parte da esquerda clandestina e o aparelho de repressão; confronto que se deu sem a participação das massas nem sequer em termos de um apoio protetor - e o resultado dessa luta desigual foi o sacrifício da imensa maioria dos quadros que constituía o "movimento armado."

Além de Marighella, escolhido por sua posição destacada, outras facções da esquerda armada compartilhariam este erro. Fora de uma situação revolucionária ou pré-revolucionária, no entanto, a guerrilha é um ato de vontade condenado ao sacrifício. E o Brasil não vivia nenhuma das duas situações. Sachs tem o cuidado de reconhecer a validade de ações armadas de defesa, para conseguir a libertação de prisioneiros, por exemplo. O que ele rejeita é a postulação da viabilidade da guerrilha como caminho da luta revolucionária naquele contexto. A expectativa de que as "massas se aglutinarão" em torno do potencial de fogo seria herdeira direta da concepção narodniki de ação direta, que o marxismo sempre combateu. Para o marxismo e o leninismo "luta armada sempre foi e continua sendo luta de classes armadas e não obra de grupos e indivíduos, por mais heroicos que se pudessem revelar. Luta armada significa armar uma classe ou uma fração de classe, em todo caso, armar massas de oprimidos." Tal como se desenrola no Brasil a luta armada seria uma "ficção", pura tática terrorista. E a suposição de que a violência revolucionária será a força que atrairá os quadros seria "regredir para uma atitude anarquista primária." ${ }^{52}$ Sachs é taxativo:

"Não há luta armada no país e não há situação que a justifique do ponto de vista da luta proletária. O que há é a tentativa de substituir a luta de classes por ações armadas de grupos isolados das massas. E seu isolamento das massas é o preço de sua sobrevivência como grupos armados". 53

Naquele 1970 as organizações que se lançaram na luta armada ainda contabilizavam resultados que eram interpretados como êxitos. Jacob Gorender considera que 1969 tinha sido o ano da "imersão geral na luta armada" ${ }^{54}$ e ainda demoraria para que a derrota impusesse a mudança de rumos. Ainda era um tempo em que, por exemplo, o POC sofria perdas de militantes atraídos pela Vanguarda Armada Revolucionária- Palmares (VAR). ${ }^{55}$ A voz da POLOP, emitida por Sachs, mais uma vez era dissonante. Sem endossar a via pacífica preconizada pelo PCB, destoava também do coro favorável à guerrilha:

\footnotetext{
${ }^{50}$ MARTINS, Ernesto (Erico Sachs). “Caminho e Caráter da Revolução Brasileira”... op. cit., p. 179-180, itálicos no original.

51 MARTINS, Ernesto (Erico Sachs). “Caminho e Caráter da Revolução Brasileira”... op. cit., p. 181.

52 MARTINS, Ernesto (Erico Sachs). “Caminho e Caráter da Revolução Brasileira”... op. cit. p. 187.

${ }^{53}$ MARTINS, Ernesto (Erico Sachs). “Caminho e Caráter da Revolução Brasileira”... op. cit., p. 187.

${ }^{54}$ Cf. GORENDER, Jacob. Combate nas trevas. A esquerda brasileira: das ilusões perdidas à luta armada. $4^{\text {a }}$ Ed., São Paulo, Ática, 1990, especialmente o capítulo 21.

${ }^{5}$ Cf. VILLA, Raul (Eder Sader). "Para um balanço da P.O”. Brasil Socialista... op. cit. A VAR tinha surgido em 1969 da fusão entre militantes do COLINA e da VPR, além de grupos dissidentes do PCB.
} 
"Quando, após todos os sacrifícios e o heroísmo individual e coletivo dos militantes (...) se descobre que tudo isso não abalou e não abala a máquina repressiva, nem a administrativa, nem o ritmo de expansão econômica (...) Quando se descobre que para a ditadura a ação dos grupos armados é uma ocasião propícia de eliminar boa parte do potencial em quadros revolucionários do país e que esse gênero de luta armada tem o efeito de alfinetadas contra o elefante, o animal enfurece-se mas não deixa de ser um elefante vivo - então chega a hora desses militantes perguntarem se não se está pagando um preço alto demais para essa experiência". ${ }^{56}$

Criticando simultaneamente o PCB e as esquerdas armadas, rompendo com o POC e enfrentando dificuldades óbvias para fazer seu trabalho junto à classe operária, ainda mais depois do AI-5 e da escalada da repressão, a OCML-PO via-se diante do fantasma do isolamento. No entanto, boa parte das organizações armadas havia incorporado elementos axiais do programa socialista da POLOP, em especial a compreensão do Brasil como sociedade capitalista e, por conseguinte, o caráter socialista da revolução. Por isso, depois que a luta armada saiu de cena, pareceu existir a possibilidade de aproximação com algumas daquelas correntes. Uma iniciativa nesta direção foi tomada por militantes exilados da POLOP, do MR-8 e da Ação Popular Marxista-Leninista (APML) que publicaram, a partir de 1975, a revista Brasil Socialista. As bases sobre as quais a revista buscava a unificação das tendências eram claramente referenciadas nas elaborações da POLOP: definem o "caráter capitalista dependente da sociedade brasileira e o caráter burguês de seu Estado", afirmam que a revolução brasileira "por suas tarefas, por seus inimigos e pelas forças sociais nela interessadas, é socialista - ou será socialista ou não será revolução", que ela não se dará por via pacífica e que o "proletariado industrial é sua força principal e dirigente". ${ }^{57}$

Todavia, nem toda a convergência quanto a tais princípios foi suficiente para assegurar a unidade em torno de uma política para combater a ditadura nessa fase. O problema já não era a guerrilha, que havia ficado para trás e que, de qualquer modo, era objeto de autocrítica por parte daquelas organizações. As dificuldades agora eram em função da posição a tomar perante a ditadura que, com Geisel, dava sinais de que rumava para o fim. O debate que teve lugar em Brasil Socialista refletiu a escalada de divergências entre a POLOP e as demais organizações quando entraram na pauta questões como as eleições ou a luta por liberdades democráticas. Foi nesse contexto, aliás, que Eder Sader (Raul Villa), um dos colaboradores mais assíduos da revista, rompeu com a POLOP. Teremos de adiar o estudo mais acurado dessa polêmica nas páginas de Brasil Socialista. As posições da POLOP foram sintetizadas num artigo publicado em abril de 1977 em outra revista e escrito, mais uma vez, por Érico Sachs sob o pseudônimo Ernesto Martins.

O texto começa com uma análise de conjuntura que leva à constatação de que a ditadura encontrava-se em posição defensiva. O próprio Geisel havia anunciado a "distensão", mas eram ainda mais significativos os pronunciamentos de expoentes da burguesia paulista pedindo o retorno à democracia. Seriam muitos os indícios de "cansaço de uma parte da burguesia da tutela da ditadura militar. Deseja retomar a influência sobre os negócios de Estado, deseja exercer diretamente seu domínio por intermédio de seus partidos e deputados no Congresso". ${ }^{58} \mathrm{O}$ fim da ditadura começava a se desenhar na cena política e era imprescindível formular a tática para lidar com os problemas que emergiam.

\footnotetext{
56 MARTINS, Ernesto (Erico Sachs). “Caminho e caráter...” op. cit., p. 194-5.

${ }^{57}$ Editorial. Brasil Socialista, ano 1, n.1, janeiro de 1975, p. 2.

58 MARTINS, Ernesto (Erico Sachs). "A crise que se avizinha... A crise pela qual passamos". In: MIRANDA, Orlando e FALCÓN, Pery (orgs.). POLOP: uma trajetória... op. cit., p. 228. O artigo saiu originalmente na revista Marxismo Militante Exterior, publicação de militantes da OCML-PO.
} 
Sachs equilibra a posição da POLOP perante a crise da ditadura em uma disjuntiva. No primeiro termo, a queda da ditadura interessa, e muito, ao proletariado: "A quebra do aparelho repressivo é necessária para que se reagrupe, movimente e organize como classe, sob bandeira própria, para continuar a luta sob condições mais favoráveis." É fácil ver que, neste nível, estão preservados os fundamentos para um amplo consenso entre todas as forças de esquerda que combatiam a ditadura e desejavam o seu fim. A dificuldade vinha na segunda parte do argumento:

"O proletariado, no entanto, não pode ter interesse que o regime militar seja seguido por uma república democrática, na qual a classe dominante exercerá sua ditadura de maneira velada, mas direta, e na qual as bases sociais, que permitiram o golpe de 64, sejam conservadas ou restabelecidas". ${ }^{9}$

Era o pomo da discórdia. O que inviabilizou a aproximação tentada entre as organizações foi a divergência acerca de questões políticas derivadas dessa premissa teórica. Sachs destaca duas delas, mencionadas acima: a tática eleitoral e a luta pelas liberdades democráticas.

Nas eleições de 1974 a APML e o MR-8 abandonaram a defesa do voto nulo, sustentada por aquelas correntes "praticamente desde a promulgação do AI-2" ${ }^{60}$, e decidiram apoiar candidaturas individuais do grupo "autêntico" do MDB. Segundo Sachs, nenhuma das duas organizações jamais explicou o que havia mudado na situação do regime para justificar sua mudança de tática. A explicação que fica, na falta de outra, é que "não souberam simplesmente resistir à onda que tomou conta das classes médias". Sachs questiona o recurso da AP à autoridade de Lênin para defender sua posição: Não teria o líder bolchevique defendido a participação na Duma tsarista? "Se os bolcheviques participaram das eleições, porque nós não podemos participar?" ${ }^{61} \mathrm{~A}$ alegação seria improcedente, porque no contexto russo os operários podiam participar como classe, com seus partidos e programas próprios, e porque dispunham da margem de atuação assegurada pela imunidade parlamentar. No Brasil, ao contrário, o proletariado só pode votar em candidatos pequeno-burgueses inscritos numa legenda partidária burguesa, o MDB. Os mais radicais dentre os candidatos, os "autênticos, não passam do nível populista pequeno-burguês (...) $\mathrm{Na}$ prática, essa tática eleitoral só tem o efeito de frear o processo de formação de uma classe operária independente no Brasil." 62

Quanto ao problema da luta por liberdades democráticas, não eram menos agudas as divergências. Como aquelas organizações invocavam Lênin em defesa de sua tática, Sachs tem de enfrentar o argumento: Lênin só afirma a validade das "tarefas democráticas" do proletariado enquanto não se completava a revolução burguesa. Após fevereiro de 1917 "desapareceram as tarefas democráticas dos objetivos de luta dos bolcheviques, que se concentraram em torno das 'tarefas socialistas' tais como agora definidas nas 'Teses de Abril."” ${ }^{63}$ Ora, aquelas forças de esquerda concordavam com a POLOP que a revolução burguesa no Brasil seria um problema superado, mas fugiam do assunto quando se tratava de formular bandeiras de luta que se articulassem com a finalidade da luta, isto é, com o caráter socialista da revolução. Não seria o caso de desprezar a importância da "defesa (ou conquista) de direitos democráticos da classe operária no seio da sociedade burguesa", materializada nas lutas pela liberdade sindical ou pela abolição do controle dos sindicatos pelo governo, por exemplo. Tal defesa tinha sido feita pela POLOP em momentos adequados como aquele quando "denunciamos os preparativos de golpes

\footnotetext{
${ }^{59}$ MARTINS, Ernesto (Erico Sachs). “A crise que se avizinha...” op. cit. p. 231.

${ }^{60}$ MARTINS, Ernesto (Erico Sachs). “A crise que se avizinha...” op. cit. p. 235.

${ }^{61}$ MARTINS, Ernesto (Erico Sachs). “A crise que se avizinha...” op. cit. p. 236.

${ }^{62}$ MARTINS, Ernesto (Erico Sachs). “A crise que se avizinha...” op. cit. p. 238.

${ }^{63}$ MARTINS, Ernesto (Erico Sachs). “A crise que se avizinha...” op. cit. p. 238.
} 
e lançamos apelos à resistência em 1964". Nada disso se confunde, porém com fazer desses direitos da classe operária

"uma 'plataforma, uma 'bandeira', um objetivo, que limita forçosamente a luta proletária. $\mathrm{Na}$ prática torna-se uma luta pela redemocratização, pela democracia burguesa, uma luta pela substituição de ditadura aberta, mas indireta, da burguesia, por uma ditadura velada, mas direta". ${ }^{64}$

Quando os objetivos da classe operária ameaçam os pilares da sociedade burguesa a "bandeira democrática se torna a bandeira da classe dominante e de seus defensores." lembra Sachs, Kautsky e Kerenski lutaram contra a revolução proletária na Rússia e Mário Soares liderou a ofensiva contra o proletariado português. Reconhecer que, no Brasil, o proletariado estava longe de assumir uma posição política independente, como nos casos históricos mencionados, deveria levar ao objetivo de construir a independência política dessa classe, o que só se conseguiria através das reivindicações baseadas em seus interesses específicos. Exatamente o contrário do que faziam a AP e o MR-8 ao proporem a acumulação de forças através das frentes amplas, alianças nas quais as reivindicações do proletariado "evidentemente não seriam aceitas pelas massas pequeno-burguesas". Em tal situação, a "fórmula vaga das lutas pelas 'liberdades' ou 'direitos democráticos' barra o caminho para a conquista da independência política da classe operária" na medida em que perpetua e aprofunda a tutela ideológica pequenoburguesa. ${ }^{66}$ Esta seria a consequência real da ampliação das alianças propostas pelas duas correntes criticadas que, ademais, seria a mesma política consagrada por trinta anos de atuação do PCB "sempre a procura de aliados pequeno-burgueses, burgueses progressistas e nacionalistasdemocráticos". Sachs cita Marx e Engels para sustentar que, quando se trata de lutar contra um inimigo comum, não é preciso união especial. Cita também Lênin que, diante da ameaça de Kornilov ao governo Kerenski, propusera "marchar separados, bater juntos."

\section{As dissonâncias e algumas distorções contemporâneas}

Não é preciso inventariar as questões que permanecem em aberto na trajetória da POLOP e, em particular, na história de sua atuação política diante dos desafios impostos pela ditadura militar. Várias dessas questões, aliás, foram explicitamente formuladas nas páginas acima e, de qualquer modo, nossa pesquisa tem muitos passos a dar ainda. Tampouco cederemos à tentação de fazer um balanço histórico-político da intervenção da POLOP nos diversos cenários da luta de classes de nossa história recente. Teremos condições bem mais consistentes para esta tarefa depois que produzirmos respostas para aquelas questões e muitas outras. Encerraremos este texto com uma referência à previsão feita por Sachs, e endossada pela OCML-PO, para o período que se abriria com o final da ditadura.

Já vimos que, para a POLOP, nada justificava engrossar o coro da oposição burguesa e pequenoburguesa da redemocratização. A classe operária não tinha qualquer interesse em restabelecer o "antigo status quo que consolidará novamente o domínio da burguesia com uma folha de parreira democrática". A consequência da queda do regime, quando viesse, seria o profundo estremecimento do "equilíbrio artificial da sociedade burguesa", de tal modo que a república democrática se caracterizaria pela incapacidade dirigente da classe dominante que, como no passado, poderia evoluir para outra experiência de ditadura aberta. Qualquer democracia, para ser

\footnotetext{
${ }^{64}$ MARTINS, Ernesto (Erico Sachs). "A crise que se avizinha...” op. cit. p. 238-9.

${ }^{65}$ MARTINS, Ernesto (Erico Sachs). “A crise que se avizinha...” op. cit. p. 239.

${ }^{66}$ MARTINS, Ernesto (Erico Sachs). "A crise que se avizinha...” op. cit., p. 240.

${ }^{67}$ MARTINS, Ernesto (Erico Sachs). “A crise que se avizinha...” op. cit., p. 142.
} 
real e duradoura, terá "que ter um caráter revolucionário, isto é, terá que se apoiar nas classes revolucionárias do país". ${ }^{68}$

De certa forma, os anos 80 parecem dar alguma razão à POLOP. Ao longo daquela década em que a classe trabalhadora experimentou um importante crescimento organizativo e político, a classe dominante teve grandes incertezas e dificuldades para recompor sua hegemonia. A ausência de unidade política se expressou em várias dimensões e uma das mais evidentes foi a dispersão da organização partidária e dos votos burgueses ao longo da década e, em particular, no primeiro turno das eleições de 1989.

Mas a POLOP não previu o transformismo! Este processo, ainda em curso, deslocou a posição da esquerda na luta de classes mantendo, no entanto, seus laços orgânicos com os trabalhadores. Foi o transformismo que viabilizou a estabilização das instituições da democracia burguesa ao apassivar a classe e marginalizar as alternativas que insistem na independência política e no caráter anticapitalista da luta dos trabalhadores. Graças ao transformismo tornou-se real a possibilidade de que as diferentes frações da burguesia não necessitassem, ao menos no primeiro momento, remover a folha de parreira democrática para consolidar a sua reunificação política com base numa plataforma estreita, porém eficiente, que é o neoliberalismo.

A tarefa política transformista conta, aliás, com a luxuosa ajuda de intelectuais de esquerda, dentre os quais alguns ex-guerrilheiros e ex-militantes da POLOP.

${ }^{68}$ MARTINS, Ernesto (Erico Sachs). “A crise que se avizinha...” op. cit. p. 149. 